\title{
Coryneform Gram Positive Bacillus
}

National Cancer Institute

\section{Source}

National Cancer Institute. Coryneform Gram Positive Bacillus. NCI Thesaurus. Code C86327.

Any bacteria whose shape is similar to those bacteria assigned to the Corynebacterium genus and have a cell wall that contains low levels of peptidoglycan and stains pink with the Gram staining technique. 